\title{
ANALYSIS OF RISK MANAGEMENT PROCESSES IN THE IT INDUSTRY
}

\author{
Mateusz TRZECIAK \\ Silesian University of Technology, Faculty of Organization and Management, Zabrze; \\ Mateusz.Trzeciak@polsl.pl, ORCID: 0000-0002-7381-3649
}

\begin{abstract}
Purpose: The aim of the article is to analyse the risk management process in IT projects managed using the agile methods.

Design/methodology/approach: The research was conducted through in-depth structured interviews on a sample of 111 project managers, leaders and project team members.

Findings: In the conducted research, attention was paid to the identification of risk factors, their assessment during project planning, management of key risk factors and the importance of risk analysis for project success. The test results were compared with a critical analysis of the literature on the subject of research.

Originality/value: The results of a survey of company heads become input information for the analysis, which allowed to confirm theoretical knowledge with the practical experience of company heads and emphasize the importance of the human factor in the risk management.
\end{abstract}

Keywords: risk, project management, IT project, Agile.

Category of the paper: Viewpoint.

\section{Introduction}

Risk management in projects has been a topic that has been raised for many years (Hottenstein, and Dean, 1992; Wyrozębski et al., 2012), although still valid (Thamhain, 2013; Cabała, 2014; Hopkin, 2017).

Unlike the traditional (cascading) approach, the agile methods treat risk as somehow a natural element (Lasek, and Adamus, 2014), but among the agile management practitioners there are popular views that if the agile methodologies are used, risk management is somewhat unnecessary. As Highsmith states, risk analysis in the agile approach to project management conducted as a separate process seems to be excessive (Walczak, 2010). In the literature, however, opinions can be made that relying on customer decisions regarding the choice of functionality and short iterations constitute a risk reduction strategy built into the Agile project 
management methods (DeMarco, and Lister, 2003). The justification is the existence of such practices as: daily meetings of team members, constant contact with the customer or short iterations.

As part of the agile approach to project management, we can distinguish both a hard approach (AgilePM, DSDM Atern, PRINCE2 Agile, PMI Agile Project Management), having a project management module, and a light approach (Scrum, Extreme Programming, Lean Management Concepts), mainly focused on project teamwork and product development.

Three different approaches to risk management can be identified in the agile approach to project management, depending on the hard or light methods used. The literature on the subject of the agile methods in a hard approach distinguishes between models based on a three-stage risk management process (identification, impact assessment, counteraction planning) during ongoing project implementation (in current iteration) and monitoring from the level of project management. An example of a risk management process is presented in Figure 1.

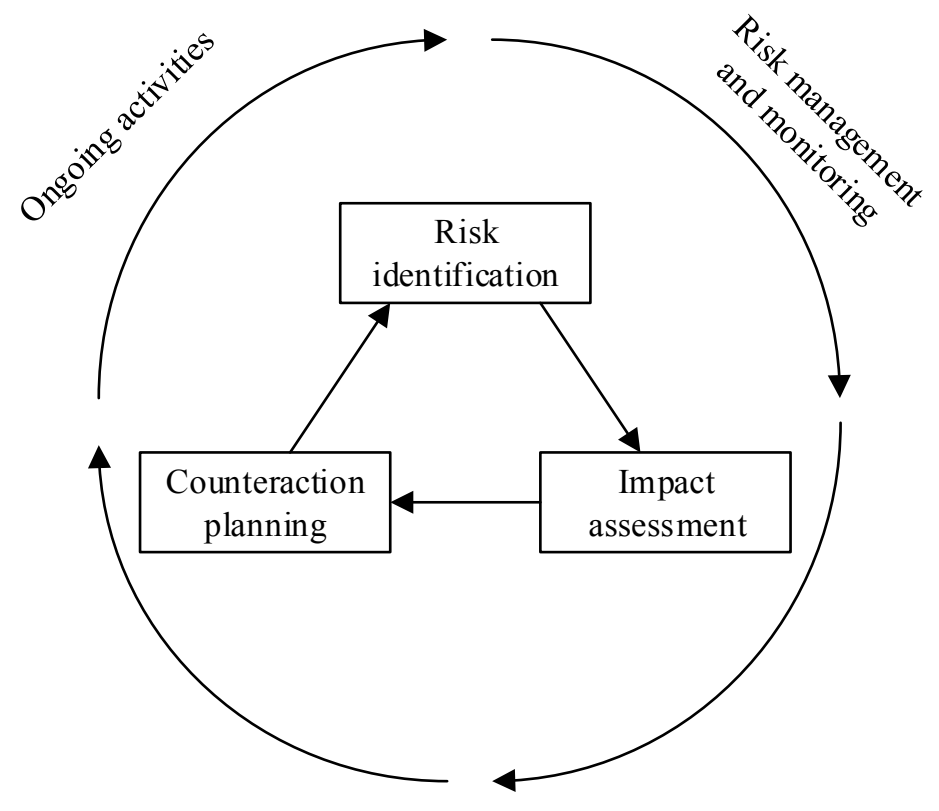

Figure 1. Risk management process in the DSDM Atern method. Own research. Adapted from: DSDM Consortium (2010), AgilePM - Agile Project Management Handbook. DSDM Consortium, V. 1.2.

In the case of the agile methods in light terms, two approaches have been developed. The first emphasises the importance of risk analysis in the project management process (Little, 2006) as an additional element performed by the team leader (Shore, and Warden, 2008; Boehm et al., 2002), however, it does not present risk management models that could be used in practice. The second approach, on the other hand, treats project risk as a natural element (Lasek, and Adamus, 2014), built into the agile methods (Walczak, 2010) through transparency, prioritisation, iterative approach or constant contact with the commissioning entity and almost immediate response to changes in both requirements and technologies or even scope elements (DeMarco, and Lister, 2003). 
In the light approach, the risk is mitigated by frequent deliveries of products (subsequent pieces of software code, modules) and constant contact with the customer. This contributes to the elimination of risk factors, resulting from the constantly changing project environment (Hopkin, 2017). However, this causes continuous changes in the scope of the project. In traditional methodologies, this could result in significant delays or increased costs, as a sufficient quick response is not possible. A light approach to project management has no such limitation. This is reflected, for example, in the risk of the customer's lack in determination and the inability to articulate expectations and needs, because, methodically, no well-specified requirements are created, that are 100\% compatible with actual customer expectations (Choetkiertikul et al., 2018). During the development of the software, the customer can specify their requirements, and even at the end of the iteration should report any comments.

\section{Research Method}

The purpose of the research was to analyse the risk management process in IT projects managed using the agile methods. In relation to the above research objective, the following research questions were adopted:

1. Are project risk factors identified as agile when planning managed projects?

2. Is Agile project management moving away from a quantitative risk assessment and towards a qualitative risk assessment?

3. Do you plan to manage key risk factors in Agile project management during planning?

4. Are agile projects drawing on the experience of others to avoid some risk factors?

5. Is the impact of IT project risk analysis significant for achieving project success?

Answering the research questions posed, structured in-depth interviews were conducted.

Considering that risk management is a process consisting of identification, assessment, monitoring and response, where individual component processes follow in succession, restrictions for the obtained test results were adopted. The following restrictions are intended to provide a broader view of the obtained research results and to define guidelines for the development of individual component processes on the proposed risk management model in the agile approach to project management:

- identification of risk factors in IT projects takes place in most cases,

- assessment of project risk factors in quantitative and qualitative terms occurs more often than sometimes,

- management of key project risk factors happens more often than sometimes. 


\subsection{Research group}

Interviews were conducted on the basis of a target group consisting of experts in the field of project management (managers and members of project teams) who had the following characteristics:

- have participated in at least one project managed using an agile method in the last 3 years,

- have practical and theoretical knowledge in the field of project management,

- they held a managerial position or of a member of the project team.

Interviews were conducted in person using an earlier prepared list of questions that was asked as follows. In order to relax the interview, at first, questions verifying the research group (personal data) were asked, and then basic questions concerning the problem. The interview was comprehensively recorded, and notes were made of respondents' answers. Interviews were conducted among 111 entities, including 38 project managers, team leaders and 73 members of project teams.

\subsection{Interview Questionnaire}

The interview questionnaire consisted of two parts. The first part was personal data (6 questions), the second answered the questions about the identification of risk factors during project planning (1 question), project risk assessment (2 questions), the importance of key risk factors (1 question), experience-based (3 questions) and impact of risk analysis on success (1 question).

The structure of the questionnaire in the research part was based on both open-ended and ranking questions, as well as on a five-point Likert scale, in which the respondents were required to indicate a specific scale of use: never (1), sometimes (2), 50/50 (3), usually (4), always (5), to each of the proposed issues.

\section{Research results}

\subsection{Identification of risk factors}

- In the surveyed sample, none of the respondents indicated that projects implemented with their participation do not identify risk factors during its planning.

- In addition, in the case of frequent use of the process associated with the identification of risk factors in IT projects, the obtained results, qualified below 50/50 projects, are outliers.

- When analysing the overall results, it should be noted that only in six cases $(5.56 \%)$, respondents declared that, while planning the project, they identified risk factors in 50/50 cases. 


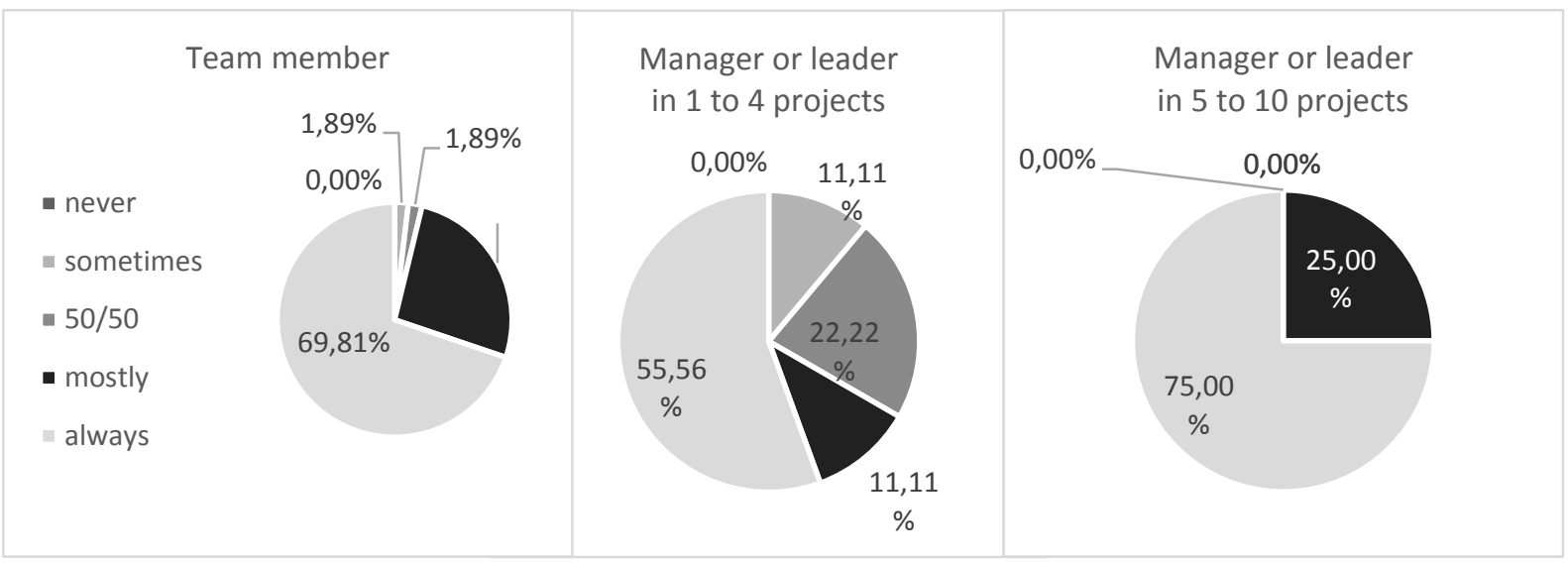

Figure 2. Identification of risk factors when planning an IT project. Own research.

Further analysis of the data drew attention to the median, which in all the analysed cases reached the value of 5. In view of the above, in most projects in which respondents participated, project risk factors are always identified.

Risk recognition (identification) consists in identifying potential threats or opportunities (risk factors) that may negatively or positively affect the implementation of the project. Unlike the traditional (cascading) approach, agile methods treat risk as a natural element (Lasek, and Adamus, 2014), although, in the literature on the subject, there is a critical approach to treating risk management used as a different process - with excess (Highsmith, 2007), agile methods directly focused on project management (e.g. AgilePM) draw attention to the importance of this process, which is also confirmed by research in this area.

In the case of criticism, it should also be emphasised that light methods (e.g. Scrum) relate directly to the management of the project and production team. At the same time, attention should be paid to the implementation of risk management processes in the light method in the form of e.g. daily meetings or frequent product deliveries (subsequent pieces of software code, modules) and constant contact with the customer. This contributes to the elimination of risk factors resulting from the constantly changing project environment (Wirkus, 2016).

\subsection{Assessment of risk factors in qualitative and quantitative terms}

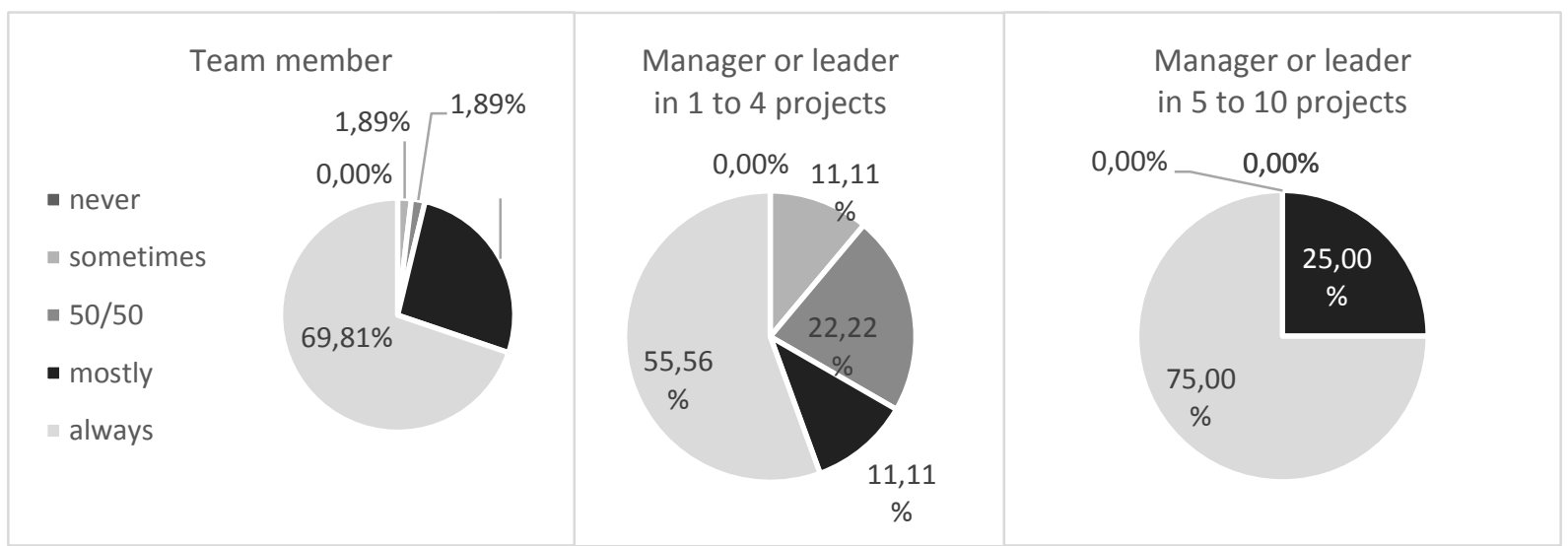

Figure 3. Assessment of risk factors in qualitative terms when planning an IT project. Own research. 


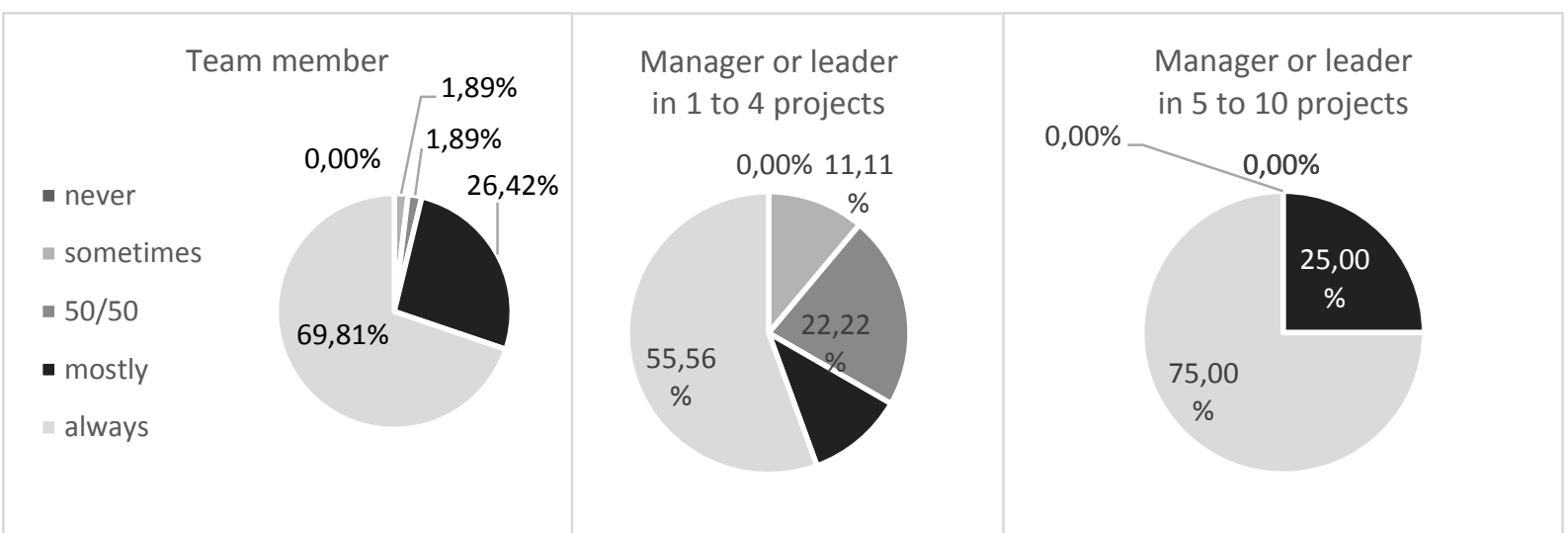

Figure 4. Assessment of risk factors in quantitative terms when planning an IT project. Own research.

When carrying out a comprehensive analysis of the results regarding both the assessment of project risk factors in both qualitative and quantitative terms, in nine cases the respondents' answers were given the value 2 (sometimes). This means that there is practically no assessment of risk factors in these cases. This is most often due to the complexity of the implemented project $^{1}$ or a light approach to Agile project management (e.g. Scrum), which does not provide for processes related to the identification and assessment of risk factors. In such cases, the risk is identified during the implementation process, i.e. review, retrospective or daily scrum.

In addition, in fifteen cases, respondents indicated that they always assess risk factors, both in qualitative and quantitative terms. In eleven cases, it was indicated that the assessment of risk factors occurs only in qualitative terms. However, using only the assessment of risk factors in quantitative terms was declared by only one respondent.

Analysing the respondents' indications regarding the use of quantitative assessment for values ( 2 - rarely) in 38 cases, the use of qualitative assessment was indicated usually ( 30 cases) or always ( 8 cases).

The presented research results are consistent with the literature on the subject (Lasek, and Adamus, 2014; Highsmith, 2007; Trzeciak, and Spałek, 2016), which also emphasises the departure from quantitative assessment in favour of qualitative with a simplified scale of implementation of risk exposure. This fact is justified by the time-consuming process of assessing risk factors on a scale up to short implementation stages, during which the majority of risk factors directly related to the technology used, product complexity or teamwork are constantly identified.

\footnotetext{
${ }^{1}$ Repetitive projects of low complexity mostly based on the knowledge and experience of the technical team.
} 


\subsection{Management of key project risk factors}

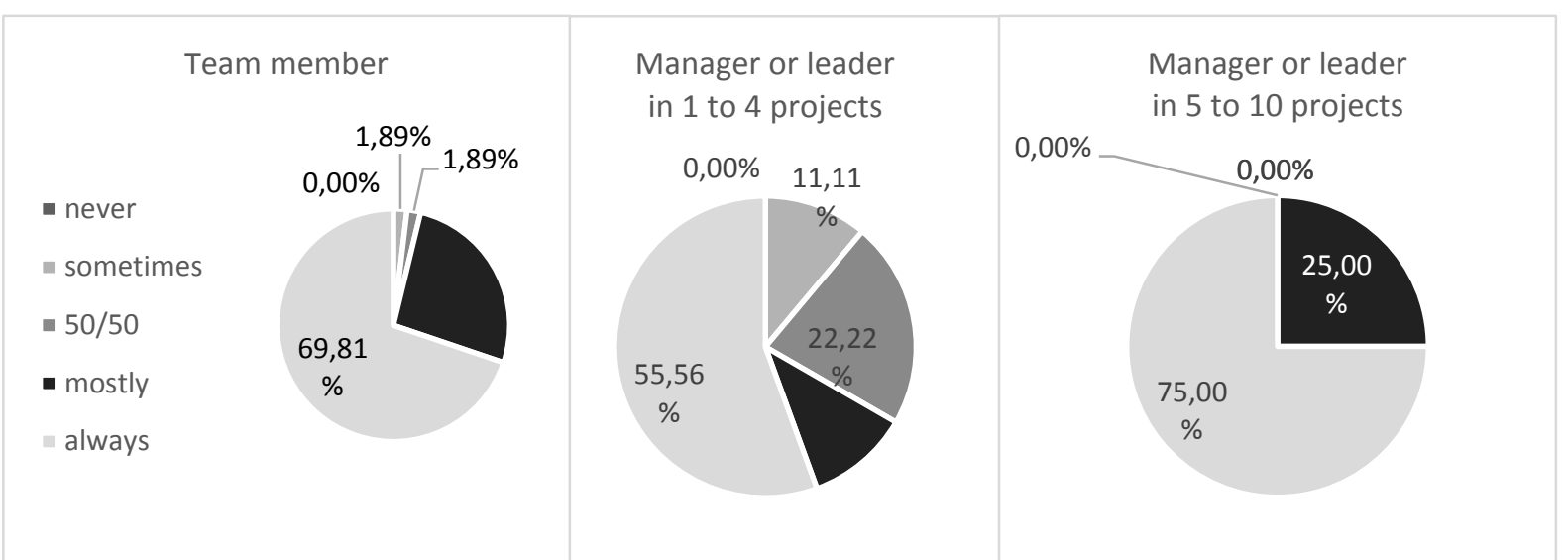

Figure 5. Planning management of key risk factors when planning an IT project. Own research.

When making a comprehensive analysis of the results, it is worth pointing out, that only 11 respondents $(12.22 \%)$ declared that during project planning they rarely plan to manage key risk factors. In addition, in three cases (3.33\%) this process is carried out in some projects $(50 / 50)$.

Management of key project risk factors in the literature (Trzeciak, and Spałek, 2016; Highsmith, 2007) regarding the agile approach to project management is only discussed in the description of the risk management process in hard methods (AXCELOS, 2015; DSDM 2014) relating to foundations in the cascade approach (Dąbrowska, 2013).

Referring the obtained research results to the literature on the subject, it should be noted, that in most of the analysed cases, respondents declare that they plan to manage key risk factors, which is not mentioned in light methods (Schwaber, and Sutherland, 2016; Berhel et al., 2015) in the agile approach to management projects. Therefore, it should be emphasised that even if it is proposed to move away from the project risk management processes in the scope of using these methods (Lasek, and Adamus, 2014; DeMarco, and Lister, 2003), executives mostly (although with different frequency depending on the nature, requirements and the complexity of the project being implemented) use risk management processes both when planning and implementing the project. 


\subsection{Drawing on the experience of others to avoid some risk factors}

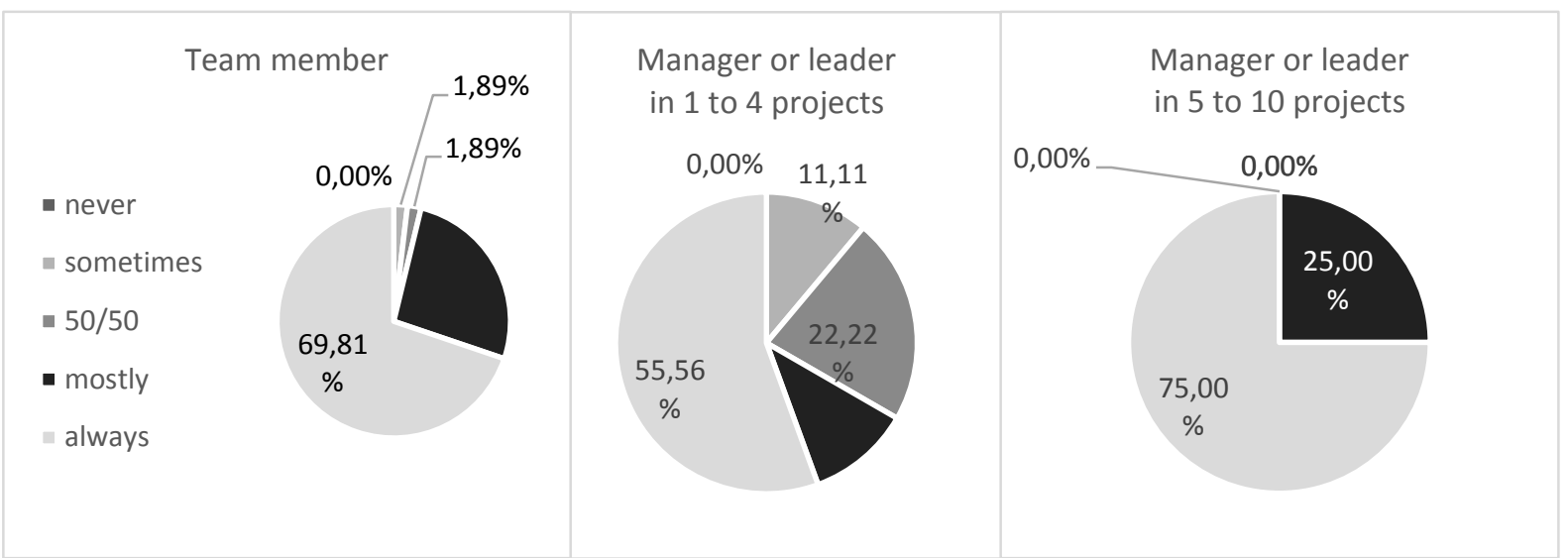

Figure 6. Drawing on the experience of others to avoid some risk factors. Own research.

Performing an overall analysis of the above survey results, $29.63 \%$ of respondents always rely on the experience of others to avoid some risk factors. In addition, $41.67 \%$ usually performs this activity. The above values constitute $71.3 \%$ of the total sample. Referring the obtained results to the literature on the subject of work principles or functioning of teams in the agile approach to project management, the role of the team leader should be emphasised. By definition, it is the person who is responsible for planning and coordinating all aspects of product delivery at a detailed level (DSDM, 2014; Pichler, 2014). On the other hand, however, it should enable the team to develop personally, gain experience and new skills. In practice, an experienced team leader (e.g. scrum master) enables the team to independently solve emerging issues, so that individual members in similar situations will know how to act and what actions to take. According to practitioners, such behaviour has a significant impact on the effectiveness and efficiency of work of individual production teams.

Another form, reflecting the research results received in the literature, is the daily occurring meetings of the software development team or weekly meetings of project leaders and/or project managers, during which each member shares their experiences, plans and problems arising during the implementation of the project.

\subsection{The importance of project risk analysis}

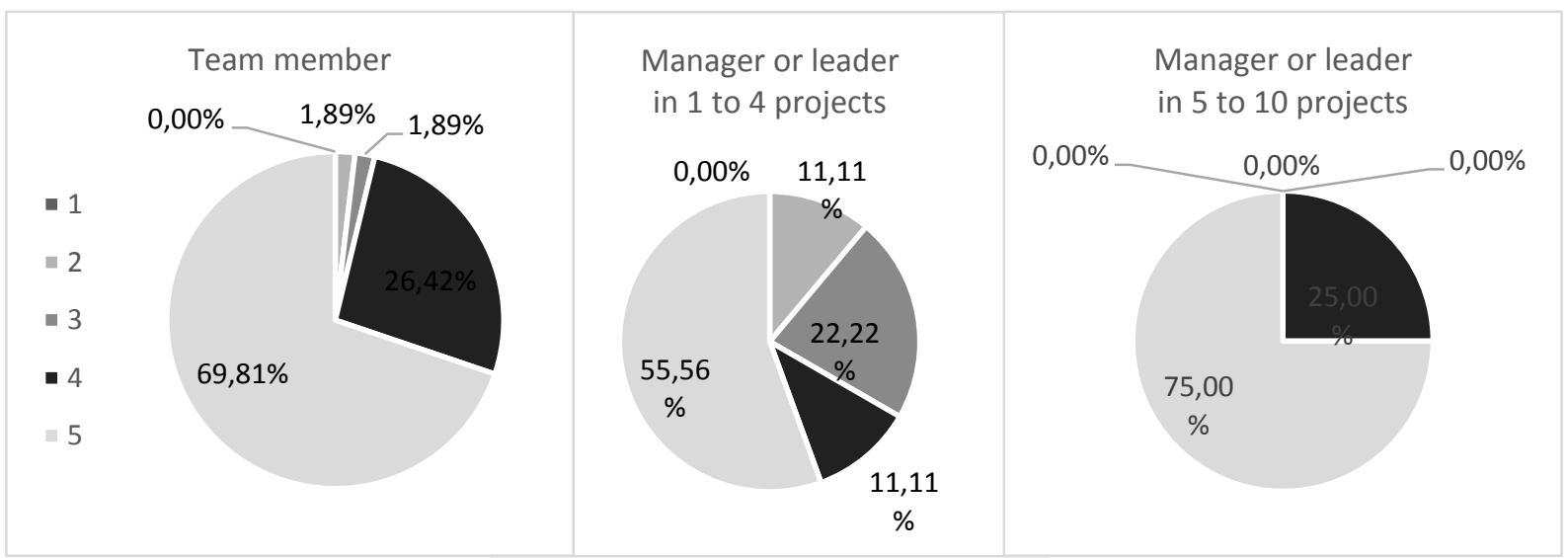

Figure 7. Impact of risk analysis on project success. Own research. 
- For the needs of this analysis, a five-point Likert scale was used, where 1 meant I definitely don't think so, 2 - I don't think so, 3 - in some cases of projects, 4 - I think so, 5 - I definitely think so.

- In the surveyed sample, the vast majority of respondents believe that the impact of risk analysis is significant for the success of the project (68.35\%).

- Values defined on a five-point Likert scale below 4 only appeared among the indications of team members $(2-3.77 \%)$ and managers and/or leaders in 1 to 4 projects $(3-33.33 \%)$.

- In addition, the value of 2 for the grouping variable for team members is an outlier measure, which is confirmed by the detailed positional measures of the analysed data.

Further analysis of the data drew attention to the median, which in all the analysed cases reached the value of 5 .

\section{Conclusions}

The literature on the subject of the agile methods in a hard approach distinguishes between models based on a three-stage risk management process (identification, impact assessment, counteraction planning) during ongoing project operation (in current iteration) and monitoring with the project management function. In the case of the agile methods in light terms, two approaches have been developed. The first emphasises the importance of risk analysis in the project management process (Little, 2006) as an additional element performed by the team leader, however, it does not present risk management models that could be used in practice. In contrast, the second approach treats project risk as a natural element (Lasek, and Adamus, 2014; Highsmith, 2007), built into the agile methods (Walczak 2010), through transparency, prioritisation, iterative approach or constant contact with the commissioning entity and almost immediate response to changes in both requirements, technologies or even scope elements (DeMarco, and Lister, 2003). Based on the above, the model approach to risk management should be characterised by simplicity of practical use, minimisation of ongoing processes directly affecting the workload of the solution development team (software), broadly understood communication also taking into account the transparency of key risk factors occurring in the ongoing project stage and/or production process (iteration).

Research on verification of IT project risk management processes implemented in an agile approach to project management ${ }^{2}$ underline the importance of the impact of risk analysis on the project's success. The analysis of the results obtained also confirms the belief that basic processes, such as recognition (identification) of risk factors, impact assessment and

\footnotetext{
${ }^{2}$ Element of author's research carried out using the standardised interview questionnaire.
} 
management of key risk factors, are used by managers and/or team leaders during the implementation of IT projects.

Out of 108 experts surveyed using the standardised interview questionnaire:

- $91.67 \%$ declare that risk factors are identified in most projects implemented with their participation,

- $82.41 \%$ declare that the impact of risk factors is assessed in qualitative and/or quantitative terms,

- $73.15 \%$ declare that, in most projects implemented with their participation, key risk factors are managed.

In addition, $68.52 \%$ of respondents who declared that, in most projects with their participation: identify, assess impact and manage key risk factors, believe that risk analysis is significant for the success of the project.

Identification and assessment of risk factors as components of risk analysis, depending on the light or hard agile methods used, take place at the level of the development team and/or design team. In light methods (e.g. Scrum), in the absence of a precise (additional) function of a project manager, which is not mentioned in the Scrum Guide (Schwaber, and Sutherland, 2017), all responsibility for project risk management (including activities related to: identification, impact assessment, response and monitoring of risk factors) is escalated to the team leader. However, if there is a formal function of a project manager or a related one with a similar scope of competence, then activities related to monitoring and response to the occurrence of key risk factors and risk factors directly resulting from the implementation of the project will take place at the level of the project team. On the other hand, activities related to the risk analysis of the production process (e.g. software) will take place at the level of the development team, which is also suggested in hard agile methods.

\section{Acknowledgements}

This paper was financed from the resources of the Silesian University of Technology, project no. BK-235/ROZ-1/2020 (13/010/BK_20/0042). 


\section{References}

1. AXCELOS (2015). PRINCE2 Agile ${ }^{\circledR}$. The Stationery Office.

2. Berhel, M., Meth, H., Maedche, A., and Werder, K. (2015). Exploring principles of usercentered agile software development: A literature review. Information and Software Technology, 61. doi: 10.1016/j.infsof.2015.01.004.

3. Cabała, P. (2014). Analiza czynników ryzyka w zarządzaniu rozwojem organizacji. Prace Naukowe Uniwersytetu Ekonomicznego we Wrocławiu, 366, pp. 68-77.

4. Choetkiertikul, M., Dam, H.K., Tran, T., Ghose, A., and Grundy, J. (2018). Predicting Delivery Capability in Iterative Software Development. IEEE Transactions on Software Engineering, 44(6), pp. 551-573. doi: 10.1109/TSE.2017.2693989.

5. Dąbrowska, A. (Ed.) (2013). Kompendium wiedzy z zarzadzania projektami (PMBoK Guide). Warszawa: MT\&DC.

6. DeMarco, T., and Lister, T. (2003). Waltzing with Bears: Managing Risk on Software Project. Dorset House.

7. DSDM Consortium (2014). AgilePM - Agile Project Management Handbook, v.2. DSDM Consortium.

8. Highsmith, J. (2007). APM - Agile Project Management: Jak tworzyć innowacyjne produkty. Warszawa: PWN.

9. Hopkin, P. (2017). Fundamentals of Risk Management: Understanding, evaluating and implementing effective risk management. London: KoganPage.

10. Hottenstein, M.P., and Dean, J.W. (1992). Managing Risk in Advanced Manufacturing Technology. California Management Review, 34(4), pp. 112-126. doi: 10.2307/41166706.

11. Lasek, M., and Adamus, A. (2014). Kiedy warto stosować metody zwinne (Agile Methodologies) w zarządzaniu projektami wytwarzania oprogramowania? Informatyka ekonomiczna, 1(31), pp. 157-172.

12. Little, T. (2006). Schedule estimation and uncertainty surrounding the cone of uncertainty. IEEE Software, 23(3), pp. 48-54. doi: 10.1109/MS.2006.82.

13. Pichler, R. (2014). Zarządzanie projektami ze Scrumem. Twórz produkty, które pokochają klienci. Gliwice: Helion.

14. Schwaber, K., and Sutherland, J. (2017). Scrum Guide ${ }^{T M}$. Przewodnik po Scrumie: Reguty gry. Retrieved from https://www.scrumguides.org/docs/scrumguide/v2017/2017-ScrumGuide-Polish.pdf, 23.11.2019.

15. Shore, J., and Warden, S. (2008). Agile Development. Filiozofia programowania zwinnego. Gliwice: Helion.

16. Thamhain, H. (2013). Managing Risk in Complex Projects. Project Management Journal, 44(2), pp. 20-35. doi: 10.1002/pmj.21325. 
17. Trzeciak, M. (2018). Modelowanie ryzyka w Agile Project Management - APM (Doctoral dissertation or Master's thesis). Zabrze: Silesian University of Technology, Faculty of Organization and Management.

18. Trzeciak, M., and Spałek, S. (2016). Zarządzanie ryzykiem w ramach metodyk tradycyjnych oraz zwinnych w zarządzaniu projektami. Zeszyty Naukowe, s. Organizacja i Zarzadzanie, 93, pp. 483-492.

19. Walczak, W. (2010). Zarządzanie ryzykiem w zwinnych metodykach zarządzania projektami. Prace Naukowe Akademii Ekonomicznej. Modelowanie preferencji a ryzyko, 10. Katowice.

20. Wirkus, M. (2016). Adaptive management approach to an infrastructure project. Procedia - Social and Behavioral Sciences, 226, pp. 414-422. doi: 10.1016/j.sbspro.2016.06.206.

21. Wyrozębski, P., Jachniewicz, M., and Metelski, W. (2012). Wiedza, dojrzałość, ryzyko w zarzadzaniu projektami. Warszawa: Oficyna Wydawnicza SGH. 